\title{
TITLE:
}

\section{$<$ News> Dr. Toshisada Nishida wins 2008 IPS Lifetime Achievement Award!}

$\operatorname{AUTHOR}(S)$ :

PAN Editors

\section{CITATION:}

PAN Editors. < News> Dr. Toshisada Nishida wins 2008 IPS Lifetime Achievement Award!. Pan Africa News 2008, 15(1): 2-3

\section{ISSUE DATE:}

2008-06

URL:

http://hdl.handle.net/2433/143490

RIGHT:

Copyright (C) Pan Africa News. 


\section{Dr. Toshisada Nishida wins 2008 IPS Lifetime Achievement Award!}

Dr. Toshisada Nishida will also be honored with 2008 Lifetime Achievement Award of the International Primatological Society at the IPS XXII Congress Edinburgh, Scotland, 3rd to 8th August 2008.

This award was established in 2004 and goes every two years to a member of IPS with outstanding career contributions to primatology. Dr. Nishida is the third winner of the award, the first being Dr. Hilary Box and the second, Dr. Thomas Struhsaker. On August 7, Dr. Nishida will give plenary lecture, "Forty Years of Chimpanzee Research at Mahale: Traditions, Changes, and Future" at the request of the executive committee for IPS 2008.

In addition to his remarkable scientific accomplishments, IPS noted Dr. Nishida's contributions to the scientific community. He has trained a generation of students at University of Tokyo and later at Kyoto University. Currently he is Professor Emeritus of Kyoto University and the Executive Director of Japan Monkey Centre. He also served as President of IPS (1996-2000), President of Primate Society of Japan (2001-2004). He is Editor-in-Chief of the oldest journal of primatology, Primates, and has served on the Editorial Boards of the International Journal of Primatology and African Primates, and the Chief Editor of Pan Africa News. 
Dr. Nishida is also known for his long-standing role in wildlife conservation. He and the late Dr. Itani embarked on a plan to establish Mahale area as a Tanzanian National Park and it was realized in 1985. In 1994, he set up a Tanzanian non-governmental organization, the Mahale Wildlife Conservation Society together with Professor Hosea Kayumbo, University of Dar es Salaam, in order to conserve the chimpanzees and other wildlife at Mahale. He has been a member of the IPS Conservation Committee (1988-1992) and the African Section of the IUCN/SSC Primate Specialist Group (1982-present). He has taken a leading role in great apes conservation as a Patron of the UNEP's Great Ape Survival Project (GRASP) and has established GRASP-Japan.

PAN Editors 